\title{
ЕПІСТОЛЯРІЙ МИКОЛИ ГОГОЛЯ У СТУДІЮВАННІ КУЛІША-РОМАНТИКА
}

\author{
К. філол. н. Свириденко О. М., \\ Україна, м. Переяслав-Хмельницький, \\ Переяслав-Хмельницький державний педагогічний університет імені Григорія Сковороди
}

DOI: https://doi.org/10.31435/rsglobal_ws/31032019/6417

\section{ARTICLE INFO}

Received: 24 January 2019

Accepted: 16 March 2019

Published: 31 March 2019

\section{KEYWORDS}

Romanticism, epistolary genre, Romanticists' publishing practice.

\begin{abstract}
The article reveals P. Kulish's studies on M. Gogol. It is established, that the actualization of the letter correspondence genre at the time of Romanticism was determined by the whole complex of literary and nonliterary causes. Here we point out to anthropocentrism of Romanticism literature, to the strengthening of the subjective origin in it, to the changes in the human concept and to the change of the artist concept (if we talk about publishing practice of Romantics) where a Romantic was proclaimed to martyr and demigod at the same time and it raised great interest to the writers' epistolary. It is stated that P. Kulish's interest to epistolary inheritance of $\mathrm{M}$. Gogol was caused by typical romantic instructions according to which a letter was proclaimed as a priority source of studying addressee's spiritual biography. Composing letters according to the chronological principle P. Kulish was directed by the aspiration to draw spiritual evolution of their author and that fully suited the publishing practice of Romantics.
\end{abstract}

Citation: Свириденко О. М. (2019) Epistoliarii Mykoly Hoholia u Studiiuvanni Kulisha-Romantyka. World Science. 3(43), Vol.3. doi: 10.31435/rsglobal_ws/31032019/6417

Copyright: (C) 2019 Свириденко О. М. This is an open-access article distributed under the terms of the Creative Commons Attribution License (CC BY). The use, distribution or reproduction in other forums is permitted, provided the original author(s) or licensor are credited and that the original publication in this journal is cited, in accordance with accepted academic practice. No use, distribution or reproduction is permitted which does not comply with these terms.

Вступ. Аналіз жанрової системи романтизму взагалі і жанрової системи українського романтизму, зокрема, дає підстави стверджувати, що «лист» як жанр у своїх усеможливих жанрових різновидах стає невід'ємним компонентом цієї системи. Актуалізація жанру листа в добу романтизму була зумовлена цілим комплексом літературних та позалітературних чинників. Йшлося про антропоцентризм романтичної літератури, про посилення суб'єктивного начала у ній, про зміну концепції людини, утвердження ії значимості як неповторної індивідуальності, а також (коли мовиться про збирацьку та едиційну практику романтиків) про зміну концепції митця, якого було проголошено мучеником і напівбогом водночас, що викликало посилений інтерес до письменницького епістолярію.

Починаючи 390 -х років минулого століття, з'являється низка грунтовних дисертаційних досліджень, у яких здійснено спробу багатоаспектного аналізу письменницького епістолярію. Частина цих досліджень (маємо на увазі праці І. Григоренко, Т. Заболотної, М. Пангелової, I. Котяш та ін.) присвячена епістолярним доробкам окремих митців (йдеться про Панаса Мирного, І. Франка, С. Черкасенка, В. Винниченка, У. Самчука та ін.) чи окремим явищам (наприклад, вивчення епістолярної літературної критики, яке здійснила Л. Вашків) у національній епістолярній традиції. У цьому контексті вирізняються наукові студії, у яких здійснено спробу цілісного розгляду епістолярного жанру в українській літературі. Мовиться про дисертації М. Назарука «Українська епістолярна проза кінця XVI-початку XVI ст.» (1994), В. Кузьменка «Письменницький епістолярій в українському літературному процесі 20-50-х років XX століття» (1999), Г.Мазохи «Жанрово-стильові модифікації українського 
письменницького епістолярію другої половини XX століття» (2007), А. Ільків «Інтимний дискурс письменницького епістолярію другої половини XIX - початку XX століть» (2016). Тобто маємо грунтовні дослідження, які у своїй сукупності цілісно прописують історію та специфіку письменницького листування в Україні.

При цьому епістолярій першої половини XIX століття, зокрема епістолярій українських письменників-романтиків, так і не став об'єктом наукових зацікавлень дослідників. До того ж, бракує досліджень, у яких би студіювалася едиційна практика романтиків.

Мета статті - проаналізувати гоголезнавчі праці П. Куліша в контексті романтичної теорії та практики.

Результати дослідження. Як відомо, романтиків цікавили будь-які прояви одкровення душі особистості, надто - особистості виняткової, геніальної, творчої. Ф. Шлегель, один із теоретиків романтизму, наголошував на самоцінності автодокументалістики (йшлося, зокрема, про зібрання листів та автобіографію), яка є унікальним джерелом вивчення духовної біографії та духовної феноменальності особистості, її внутрішньої квінтесенції. У «Листі про роман» Ф. Шлегеля Антоніо закликає Амалію, якій адресовано лист, читати не низькопробні романи 3 тривіальними сюжетами, а життєписи непересічних особистостей, які самі по собі є романами: «Надсилаю Вам автобіографію знаменитої людини, з якою (автобіографією), наскільки мені відомо, Ви ще не знайомі, - «Мемуари» Гіббона. Це безмежно наукова й безмежно кумедна книга. Вона відразу Вам сподобається, адже у ній міститься фактично готовий комічний роман». Він пояснює Амалії, що за рядками мемуарів цього історика вона побачить не історію і не історика. Читаючи мемуари, вона відчує духовну неповторність Е. Гіббона: «Перед Вами постане в усій своїй комічній манірності англієць, джентльмен, віртуоз, учений, старий парубок, людина витончена й елегантна. Ясна річ, можна прочитати чимало поганих книжок й надивитися на велику кількість нікчемних людей, перш ніж трапиться така купа смішного матеріалу, зібраного докупи» [4, с. 406].

Розглядаючи лист як духовний феномен, як відбиток духовної біографії, романтики (європейські взагалі й українські зокрема) демонструють посилений інтерес до епістолярної спадщини видатних людей, оскільки духовно розвинена особистість $є$ для них ідеалом. У цьому контексті знаковим $є$ одне 3 висловлювань Ф. Шлегеля: «Кожна розвинута людина, яка працює над собою, містить у собі роман, утім зовсім не обов'язково, щоб вона його ще й писала» $[4, \mathrm{c}$. 284]. Тож, за романтичною теорією, листи непересічної особистості, вийшовши з глибин іiі душі, можуть самі по собі в свойй сукупності скласти роман. Усе це позначилося і на сприйнятті романтиками вже опублікованого епістолярію, і на тому, як самі вони підходили до видання епістолярної спадщини видатних людей того часу. Характерно, що романтики прагнуть видавати не просто листи, вони орієнтуються саме на зібрання листів, що зумовлювалося власне романтичною настановою на простеження історії духу, прагненням простежити плин почуттів і душевних настроїв автора листів, його духовну еволюцію. Подібна настанова романтиків позначилася на жанровій системі романтизму взагалі і призвела до появи поетичних циклів, які, за висловом Н. Копистянської, стали великим жанровим досягненням романтиків [1, с. 295]. На добу романтизму припадає й видання перших епістолярних циклів.

Посилений інтерес до письменницького епістолярію, який демонструють романтики, проявився у збиранні, колекціонуванні та публікації письменницьких епістол. Йшлося також про спроби дати науковий коментар до опублікованого, виробити методологічні підходи до вивчення епістолярію і навіть про перші спроби пов'язати поетику листа 3 поетикою того літературного напряму, що його представляв адресант-письменник.

Знаковими у цьому контексті є гоголезнавчі студії П. Куліша, які стосувалися насамперед епістолярної спадщини митця. Лист письменника Куліш-романтик вважав найціннішим i найдостовірнішим джерелом вивчення його біографії, але біографії насамперед у ії романтичному розумінні, тобто «біографії духу». Такі методологічні підходи застосовує П. Куліш, публікуючи епістоли М. Гоголя, які в комплексі мали скласти духовну біографію цього прозаїка.

Першим досвідом такої біографії стали замітки П. Куліша «Несколько черт для биографии Н.В. Гоголя», опубліковані в «Отечественных записках». Ці ж замітки у цьому ж таки році були опубліковані у Петербурзі також окремою відбиткою, що мала назву «Несколько слов о Гоголе (Отрывок литературного письма)». 
Наступним кроком П. Куліша в опануванні феномену М. Гоголя став «Опыт биографии Н.В. Гоголя со включением до сорока его писем. Сочинение Николая М.», опублікований у 1854 р. в «Современнике» (№2-4), а також окремою відбиткою. За спостереженнями Ж. Ляхової, «Опыт...» був першою спробою біографічного дослідження не лише про Гоголя, а й про письменника загалом, у структурі дослідження якого домінантну роль відігравав його епістолярій. ... Підходячи до листів Гоголя як до автентичного джерела дослідження його людської і творчої індивідуальності, П. Куліш уперше в українському та російському літературознавстві впроваджує "психографічний" метод у роботі над біографією письменника». [3, с. 36]. Власне кажучи, П. Куліш пішов тим же шляхом, яким рухався Ф.Шлегель, досліджуючи феномен Г.-Е. Лессінга крізь призму його епістолярної спадщини, яка тлумачилася як пріоритетна на тлі будь-якого іншого матеріалу.

У «Опыте...», що мав типово романтичну мозаїчну композицію, окрім листів М. Гоголя, присутні розлогі авторські коментарі. Ці коментарі передують листам, немов готуючи читача до сприйняття тих фактів, рецепція яких буде подана в епістолах. Ставлячись до листа як до документа, П. Куліш, якщо й робить певні правки в автографах, то завжди обумовлює i прописує це в коментарях. Так, листи Гоголя-гімназиста не відрізнялись дотриманням орфографічних правил, тому П. Куліш дозволяв собі зробити в них деякі правки. Втручання П. Куліша в тексти автографів пояснювалися також тією обставиною, що чимало адресантів чи просто осіб, які згадувалися в листах М. Гоголя на момент публікації «Опыта...» ще були живими, а тому видавець 3 етичних міркувань не розголошував їхніх імен, удаючись при цьому до скорочень, про що попереджав у коментарях: «Имена, сокращенные мною в начальные буквы, будут везде отмечены тремя звездочками; начальные же буквы, выставленные вместо имен самим Гоголем, не будут иметь при себе звездочек» [2, с. 25]. Нерідко у дослідженні зустрічаємо примітку на зразок: «С этого места переменились чернила и почерк сделался небрежнее» [2, с. 28], що свідчило про увагу П. Куліша до зовнішнього боку епістол.

П. Куліш демонструє посилену увагу до почерку М. Гоголя, простежуючи всеможливі зміни у ньому і пов'язуючи ці зміни (зміни на краще) з духовним саморухом митця: «Извинение Гоголя в том, что он пишет небрежными почерком, показалось мне сперва очень странным. Он вообще не отличался каллиграфическим искусством, и все письма его кроме одного или двух, которые он переписал по особенным причинам набело писаны крайне небрежно, чем бы перо не было очинено, ножиком или ножницами. Но потом смысл этих слов объяснился для меня как нельзя удовлетворительнее. Трудясь над своим перевоспитанием, он не оставил без внимания и своего почерка. Последние письма его к П.А.Плетневу обнаруживают явное подражание почерку прописей и даже попытку на щеголеватость букв. Не скажу, чтоб он иного успел в каллиграфии, но некоторые из его предсмертных писем до такой степени отличаются от писем прежней эпохи, что если бы не было постепенного перехода к ним от его обыкновенных каракулей, то можно было бы принять их за чужие рукописи» [2, с. 28].

Окрім авторських коментарів у першій частині студії уміщено також оповідання Данилевського про М. Гоголя, що вперше було опубліковане в «Московских ведомостях» (1852, №124). Цитуючи це оповідання, П. Куліш намагався дати читачеві максимально повне уявлення про малу батьківщину Гоголя-романтика. Це оповідання - своєрідний місток до другої частини книги, яка описує переїзд М. Гоголя до Петербурга, звідки його душа, за П. Кулішем, нерідко літала за натхненням на Полтавщину.

Друга і третя частини книги скомпонована за тим же мозаїчно-фрагментарним принципом: біографія М. Гоголя, яку переповідає П. Куліш, цитування мемуарів сучасників М. Гоголя і навіть його улюблених пісень. Звичайно, на першому місці стоїть цитування його власних листів, адресованих М. Максимовичу, П. Плетньову, М. Щепкіну, М. Білозерському та іншим. Прагнучи дати читачам якомога повнішу біографію М.Гоголя, «сохранившуюся в его письмах» [2, с. 149], П. Куліш жалкує, наприклад, із приводу того, що у нього відсутні листи М. Гоголя до В. Жуковського. Утім, зважаючи на важливість справи, на необхідність створення духовної біографії М. Гоголя на матеріалі ще невтрачених листів, П. Куліш констатував, що він «желает лучше быть в своем изложении отрывочным, нежели пренебречь каким-нибудь известным ему моментом жизни поэта» [2, с. 140].

I хоча гоголезнавча студія П. Куліша в цілому мала фрагментарний характер, до цілісності дослідник усе ж таки прагнув. Особливо, коли йшлося про створення цілісного 
образу М. Гоголя на матеріалі його епістолярного доробку, коли мовилося про спробу показати особистість митця у різні періоди життя і творчості, а також його духовну еволюцію впродовж усього життя. Тому П. Куліш детально обмірковує принципи компонування епістолярного матеріалу. Він викладає листи не за принципом адресата, а за хронологією написання, тому, наприклад, листи від М. Максимовича читач знайде у різних частинах цієї книги.

П. Куліш тлумачив свою гоголезнавчу студію прагненням вберегти від забуття листи митця, які на той час перебували у приватних домашніх архівах М. Максимовича, О. Бодянського, М. Щепкіна та інших осіб, із якими листувався М. Гоголь. Водночас автор говорить також про спробу «вияснити» для себе особистість М. Гоголя. Здійснюючи огляд здобутків вітчизняної словесності на тлі світової літератури, Куліш-романтик висловлював свій жаль 3 приводу того, що Україна відстає у творенні життєписів: «Жаль, что мы не вошли еще, так сказать, во вкус биографии и как-то холодно собираем материал для этого рода сочинений». До того ж, він закладає саме романтичні підвалини біографістики, адже у біографії, на його думку, мають бути поєднані «серьезный интерес истории, глубокие психологические исследования и самый роскошный романтизм» [2, с. 140]. Тобто П. Куліш веде мову саме про духовну біографію, матеріалом для якої може послужити насамперед епістолярна спадщина. Взірцеві зразки подібних біографій він знаходив у світовій практиці, зокрема в доробку В. Скотта, В. Ірвінга та Т. Мура, у поле зору яких потрапляли життєписи Джорджа Байрона, Наполеона Бонапарта, Христофора Колумба та інших видатних особистостей. «Будем надеяться, что и наши знаменитые личности не останутся без подробных мемуаров для будущих биографов» [2, с. 140], - підсумовував П. Куліш, продовжуючи свої власні студії над життєписом М.Гоголя й закликаючи сучасників до подібної праці.

У 1856 році Куліш-романтик публікує новий (розширений) варіант своєї студії про М. Гоголя, даючи їй нову назву «Записки о жизни Н.В. Гоголя, составленные из воспоминаний его друзей и знакомых и из его собственных писем, с портретом Н.В. Гоголя. В 2 т.» (Спб., 1856). Цього разу він публікує близько 800 листів, які дозволили заповнити йому ті білі плями в біографії М. Гоголя, які, на його думку, існували в «Опыте...». І хоча ця студія була створена на основі попередньої, П. Куліш з багатьох причин вважав ії цілком новим біографічним дослідженням. Він навіть змінюе назву праці. І ця нова назва цілком розкривала специфіку студії, принцип компонування матеріалу у ній. У передмові сам П. Куліш зазначав, що він вирішив призупинитися з біографічними висновками. Присутність автора в новій гоголезнавчій студії П. Куліша стає менш помітною. Цього разу П. Куліш перетворив свою книгу у звичайний збірник відомостей про М. Гоголя, зокрема його листів, які згодом, як він сподівався, стануть матеріалом для написання біографії М. Гоголя.

Висновки. Отже, зацікавлення П. Куліша епістолярною спадщиною М. Гоголя було зумовлене типово романтичними настановами, згідно 3 якими лист проголошувався пріоритетним джерелом вивчення духовної біографії адресанта. Компонуючи листи за хронологічним принципом, П. Куліш керувався прагненням накреслити духовну еволюцію їх автора, що цілком відповідало романтичній едиційній практиці.

\section{ЛІТЕРАТУРА}

1. Копистянська Н. Х. Жанр, жанрова система у просторі літературознавства. Львів: Паіс, 2005. 367 с.

2. Кулиш П.А. Опыт биографии Н.В.Гоголя. Кулиш П.А. Опьт биографии Н.В.Гоголя А.Т. Тарасенков. Последние дни жизни Н.В. Гоголя. Н.Котляревский. Н.В. Гоголь. Москва: Альтернатива-Евролинц, 2003. C.10-167.

3. Ляхова Ж. Епістолярій Миколи Гоголя як художнє саморозкриття особистості в дослідженнях П.Куліша. Література та культура Полісся. Ніжин: НДУ ім. М.Гоголя, 2008. Вип. 45. С.35-64.

4. Шлегель Ф.Эстетика. Философия. Критика: В 2-х томах. Москва: Искусство, 1983. Т.1. 479 с. 